\title{
Effects of Teaching and Learning Supervision on Teachers Attitudes to Supervision at Secondary School in Kubang Pasu District, Kedah
}

\section{Hareesol Khun-inkeeree}

Walailak University, Thailand, sol.khun75@gmail.com

\section{Puteri Darishah Dali}

College of Arts and Sciences, Universiti Utara Malaysia, Malaysia, pu3darishah@gmail.com

\section{Yaakob Daud,}

College of Arts and Sciences, Universiti Utara Malaysia, Malaysia

\section{Mohd Sofian Omar Fauzee}

College of Arts and Sciences, Universiti Utara Malaysia, Malaysia

\section{Rozalina Khalid}

College of Arts and Sciences, Universiti Utara Malaysia, Malaysia, rozalina@uum.edu.my supervision on the attitude of teachers towards the supervision in secondary schools in Kubang Pasu District, Kedah. The supervisory model developed by Glickman, Gordon and Ross-Gordon (2004) and the research instrument involves a set of questionnaires containing 23 items. Respondents of the study involved 372 teachers in secondary schools in Kubang Pasu District, Kedah. The data were analyzed using descriptive statistics using Statistical Packages of Social Sciences and inferential statistics using the Partial Least Squares software through the SMART PLS 3.0 software. The result shows that there is a significant influence between the dimensions of knowledge and the technical skills with the teachers' attitude towards supervision while the dimensions of interpersonal skills do not have a significant influence on teachers' attitudes. The findings can be used as guidance to the Ministry of Education, to overcome all the shortcomings and weaknesses in the existing teaching supervision practices based on the established supervisory regulation.

Keywords: teaching, learning, supervision, teachers' attitude, secondary schools

Citation: Khun-inkeeree, H., Dali, P. D., Daud, Y., Fauzee, M. S. O., \& Khalid, R. (2019). Effects of Teaching and Learning Supervision on Teachers Attitudes to Supervision at Secondary School in Kubang Pasu District, Kedah. International Journal of Instruction, 12(1), 1335-1350. https://doi.org/10.29333/iji.2019.12185a 


\section{INTRODUCTION}

The implementation of teaching and learning supervision in the classroom is a process aimed at improving the effectiveness of teachers' teaching competency as well as improving academic progress or performance amongst students (Ministry of Education, 2012). As specified in the Malaysian Education Development Plan that is "Teaching activities that improve the quality of teaching and learning in schools directly such as teaching supervision and curriculum planning, have a higher impact on student achievement" (MEDP, 2013-2025, p.5-17). The implementation of quality teaching and learning supervision requires supervisors who master knowledge, interpersonal skills and technical skills (Glickman et.al, 2004) specialized in teaching, tracking and assessment curricula as well as good humanitarian relations. Competence in conducting supervision enables them to help teachers to improve their competence in implementing effective teaching processes in the classroom (Glickman, 1981).

\section{Background of Study}

The Malayan High Education Report Malaya (1939), Barnes Report (1951) and Razak Report (1956), has suggested establishing the Federal Inspectorate as a professional body responsible for monitoring and supervising teachers' teaching in schools (Ahmad Kamal, Abd. Rahman and Zuraidah, 2015). This is because the supervisory process has existed around the 1950s and early 1960s through the supervision of the Inspectorate (KPM, 2010). In 1987, the Ministry of Education has issued directions through the Professional Circular Letter No. 3/1987 KP (BS) 8591/vol. 11 (77), dated 11 November 1987, related to classroom teaching and learning supervision and at present, is still practiced. The directive focuses on the supervisory of prioritised task in the context of improvement, enhancement of teaching and learning and the opportunity of professionalism sharing between the evaluation conducted by the Inspectorate and also the principal (MOE, 1987). This can be a platform to improve the teaching and learning process in line with the government's aspiration to make Malaysian education system at par with international education (MOE, 2010).

In order to achieve this, supervisory issues towards improving the quality of the teaching profession are continuously given priority by the Ministry of Education Malaysia (Ahmad Kamal, Abd. Rahman and Zuraidah, 2015; Hamidah, Jamal and Sharifah, 2016). This leads to the standardization of the quality of education services that need to be improved and upgraded from time to time through teaching and learning quality in the classroom. However, this aspect can only be done by consistently supervising the teaching of academic teachers in schools that need to be strengthened through knowledge, interpersonal skills and technical skills.

\section{Problem Statement}

Teachers assume teaching in the classroom is their right of authority while their capability and expertise in teaching is not the power of the principal to assess it (Mohd and Aziz, 2014). The perception is on the rationale that there is no provision for a supervisor's post and their presumption that the school system has no supervisor (Ahmad Kamal, Abd. Rahman and Zuraidah, 2014; Mohd Munaim, 2013; Vijayaamalar and 
Suhaida, 2013). Therefore, the supervisory system is questionable and it is in line with the views by Mardhiah and Rabiatul (2016). Furthermore, the findings by Vijayaamalar and Suhaida (2013) showed surprising results that 20 percent of teachers like to be supervised, while 80 percent of teachers do not like to be supervised. This finding shows that teachers in Malaysia do not want to be observed or assessed and do not want to accept the weaknesses they might have in their teaching process. As a result, teachers' teaching proficiency is difficult to be measured and thus cannot be improved (Mat Rahimi and Mohd, 2015). Hence, this issue has attracted the researchers to examine the influence of teaching and learning supervision dimensions on teachers' attitude towards supervision.

In examining this issue, it is found that the reason teacher being negative towards the supervision is due to their dissatisfaction with the management of supervision (Vijayaamalar and Suhaida, 2013). This negative attitude is caused by supervision done if the teacher has to be promoted, confirmation of status or the teacher is being disciplined because of their teaching performance (Hamdan and Mohd Ali, 2011; Mohd Hamsan, 2002). Hence, Shukri (2004) opined that teachers' negative attitude towards supervision is because teachers feel threatened that their annual performance assessment would also be influenced. They believe that supervision is summative assessment and does not benefit or improve the quality of their teaching. This scenario results in a lack of guidance for teachers and the effects of which teachers are faced with teaching problems. In addition, it is found that teachers have doubts about the supervision performed by the principals (Muhamad Sani, 2002) because they doubt the principal's ability and expertise in the subject they teach (Tang and Abdul Ghani, 2007). The doubts arise as there are no special courses related to the supervision given to the principals (Mardhiah and Rabiatul, 2016). It is found that principals do not carry out professional responsibilities and are not actively involved in the supervisory process (Chan and Gurnam, 2009).

Consecutively, Vijayaamalar and Suhaida (2013) state that teachers do not receive the similar number of supervisory and only 13.6 per cent of teachers are supervised three times a year, 26 per cent are supervised twice and 60.4 per cent are supervised once a year. This proves that the supervisory process does not follow the actual concepts as directed. As such, Hamdan and Mohd Ali (2011) view that the supervisory practices are not properly followed and failed to be implemented in a transparent manner. As a result, teachers' professional development is stunted (Haliza, 2005). Due to this problem Ahmad Kamal et al., (2014) criticized that no monitoring by MOE, SED and DEO on supervisory practices has led to the uncorrected teacher's attitude towards teaching and learning supervision.

However, there is a study that finds supervision has an effect on the attitude of the teacher (James and Balasandran, 2012; Vijayaamalar and Suhaida, 2013; Wan Shafira, 2011) but the finding was not supported by result by Meor Ibrahim and Norziana (2008) that the autocratic or bureaucratic supervision did not affect the attitude of the teacher as there was no co-operation, discussion and feedback between the supervisor and the supervised teacher. However, Mat Rahimi and Mohd Yusri (2015) stressed that 
there was no consistent study findings regarding supervision that had an impact on attitudes at school. Therefore, classroom teaching and learning supervisory study on teacher attitude is conducted to obtain the actual results of the study.

\section{Purpose and Objectives of Study}

This study was conducted to examine the influence of teaching and learning supervision on the attitude of teachers in secondary schools in Kubang Pasu District, Kedah. This study will also focus on several aspects, namely validating constructs in teaching and learning supervision dimensions and also the constructs of teachers' attitude toward supervision and the contribution of knowledge dimension, interpersonal skills and technical skills towards teacher attitude.

\section{Research Hypotheses}

Ho1: There is no significant influence between knowledge and teacher attitude toward supervision.

Ho2: There is no significant influence between interpersonal skills and teacher attitude toward supervision.

Ho3: There is no significant influence between technical skills and teacher attitude toward supervision.

\section{METHOD}

\section{Study Design}

This study was conducted using a quantitative approach. The questionnaire was used as an instrument to examine the attitude of teachers in secondary schools in the Kubang Pasu District, Kedah on the supervision of teaching and learning in secondary schools.

\section{Data Collection Method}

A total of 372 sets of questionnaires were distributed to respondents consisting of academic teachers at 14 Secondary Schools in Kubang Pasu District, Kedah. From that total, 345 sets of questionnaires were returned and resulted in a welcome rate of $92.74 \%$. Of the 345 sets of questionnaires returned, 311 sets of questionnaires were successfully analyzed to produce a percentage of $90.14 \%$. While 29 sets of questionnaire equivalent to $8.41 \%$ could not be analyzed well because the respondents did not complete the items in the questionnaire perfectly and as many as 5 sets of questionnaire, $1.45 \%$ had problematic data problems. Table 1 shows a summary of the number of questionnaires used in this study. 
Table 1

Summary of the Number of Questionnaires used in the Study

\begin{tabular}{lcc}
\hline Questionnaire & Number $(n)$ & Percentage \\
\hline Distributed & 372 & 100.00 \\
Returned & 345 & 92.74 \\
Returned and complete & 316 & 91.59 \\
Returned but incomplete & 29 & 8.41 \\
Outliers thus dismissed & 5 & 1.45 \\
Successfully analyzed & 311 & 90.14 \\
\hline
\end{tabular}

\section{Study Instrument}

The questionnaire used in this study was a questionnaire adapted from Ebmeier (2003) for the teaching and learning supervisory variables. The questionnaire of teacher attitude toward supervision was adapted from Ramin et al. (2014). The items of the questionnaire are shown in the table below.

Table 2

Teaching and Learning Supervision Details

\begin{tabular}{ll}
\hline Details & Items \\
\hline Knowledge & I have confidence in the teaching and learning supervisor \\
I am satisfied with my confidence in the teaching and learning \\
supervisor \\
I am satisfied with the ability of the teaching and learning supervisor \\
I am satisfied with the professional leadership of the teaching and \\
learning supervisor. \\
There is an open communication between teachers and supervisors. \\
The decision made in the supervision is fair \\
My supervisor is very supportive in my quest to be a good teacher. \\
The supervisor really helped me to try to improve teaching in the \\
classroom. \\
Myterpersonal Skills supervisor honestly cares about helping to improve teaching \\
techniques. \\
I really believe the supervisor really cares about improving me as a \\
professional. \\
I am very confident that the supervisor really cares about improving me \\
as a professional. \\
As part of the supervisory cycle, supervisors regularly collect data to \\
help me improve the way we teach. \\
During a supervisory session, the supervisor is very helpful to \\
implement the goals that I can achieve. \\
As a result of my supervisor's supervision during a supervisory session, \\
I was tempted to evaluate my own teaching. \\
During the supervisory session, the supervisor asked the question that \\
made me really think. \\
My supervisor often talks about the teaching strategies I use in the \\
classroom.
\end{tabular}

(Source: Ebmeier, 2003)

International Journal of Instruction, January2019 • Vol.12, No.1 
Table 3

Details of Teacher Attitude on Supervision

\begin{tabular}{ll}
\hline Details & Items \\
\hline Teacher's Attitude & Supervisor is more towards finding teachers' weaknesses. \\
towards Supervision & Supervision done is trustworthy. \\
& The supervision is aimed at sharing shared responsibilities between \\
& teachers and supervisors. \\
& Supervision is performed with the aim of control rather than \\
& upgrading. \\
& Supervision is an examination and not a cooperation process. \\
& Supervision creates excitement for teachers. \\
& Supervision focuses heavily on teachers.
\end{tabular}

(Source: Ramin et al., 2014)

\section{Data Analysis}

The data were analyzed using descriptive analysis using Statistical Packages of Social Sciences (SPSS) for Window 22.0. Inferential analysis was analyzed using the Partial Least Squares (PLS-SEM) software through the Smart PLS 3.0 software, followed by the formation of reflective measurement model and the structure equation model.

Table 4

Distribution of Respondents by Sex, Age, Teaching Experience $(n=311)$

\begin{tabular}{llll}
\hline Profile & Factor & Number & Percentage \\
\hline Gender & Male & 96 & 30.8 \\
& Female & 215 & 69.2 \\
Age & Total & 311 & 100.0 \\
& $<25$ years & 3 & 0.9 \\
& 26 to 35 & 59 & 18.9 \\
& 36 to 45 & 114 & 36.7 \\
Teaching Experience & $>45$ years & 135 & 44.4 \\
& Total & 311 & 100.0 \\
& 1 to 5 years & 10 & 3.2 \\
& 6 to 10 years & 49 & 15.8 \\
Supervised by & 11 to 15 years & 89 & 28.6 \\
& $>15$ years & 163 & 52.4 \\
& Total & 311 & 100.0 \\
& Principal only & 28 & 9.0 \\
& Senior Assistant & 86 & 27.7 \\
& Senior Teacher & 137 & 44.0 \\
& Panitia Head & 36 & 11.6 \\
& SIC+ & 24 & 7.7 \\
& Total & 311 & 100.0 \\
\hline
\end{tabular}




\section{FINDINGS}

\section{Assessment Model Evaluation}

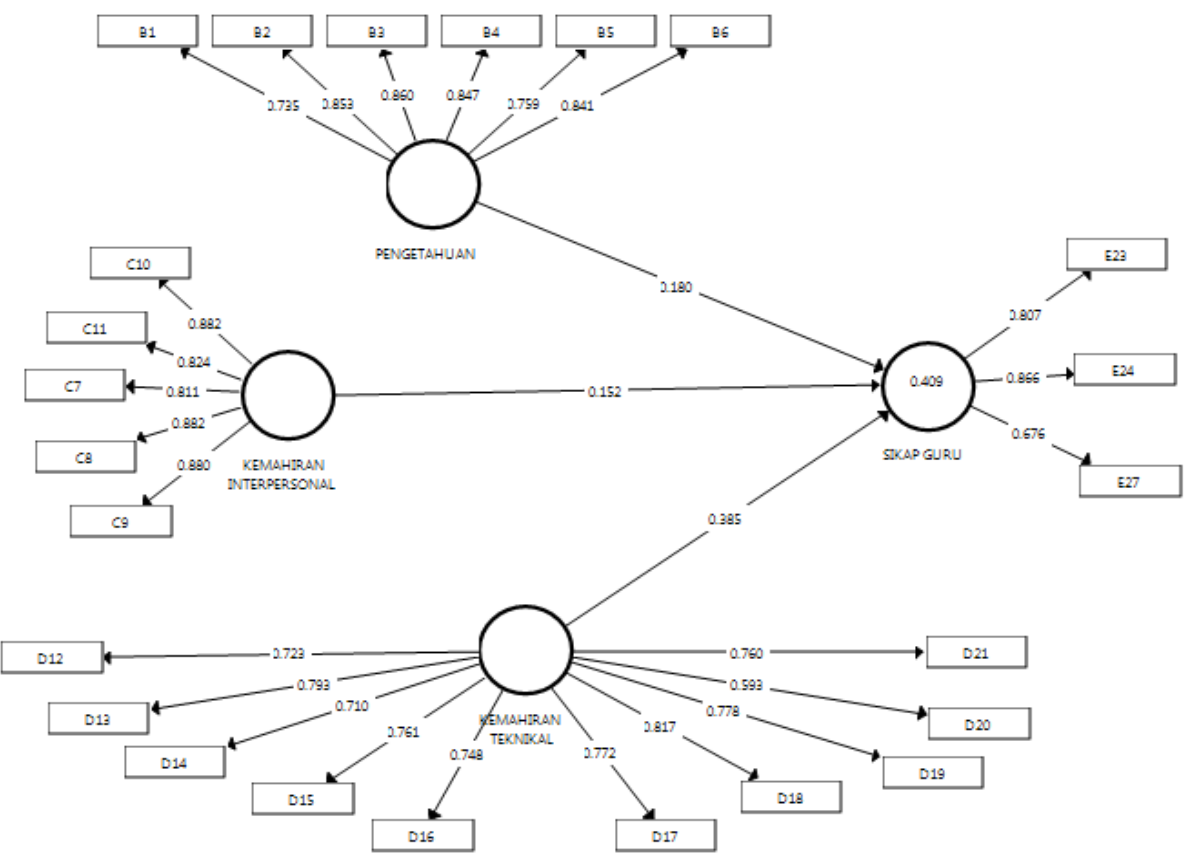

Diagram 1

Assessment Model Analysis Result

Diagram 1 shows the results of the assessment model analysis. Four aspects were evaluated based on the measurement model, namely internal consistency, reliability of indicators based on external loading values, convergence validity and discriminant validity.

\section{Internal Consistency}

Table 5

Summary of Cronbach's Alpha analysis and Composite Reliability analysis

\begin{tabular}{llll}
\hline Constructs & $\begin{array}{l}\text { No. of } \\
\text { Indicator }\end{array}$ & $\begin{array}{l}\text { Cronbach's } \\
\text { Alpha }\end{array}$ & Composite Reliability \\
\hline Knowledge & 06 & .900 & .923 \\
Interpersonal Skills & 05 & .909 & .932 \\
Technical Skills & 10 & .911 & .927 \\
Teachers' attitude towards supervision & 03 & .693 & .828 \\
\hline
\end{tabular}

International Journal of Instruction, January2019• Vol.12, No.1 
Table 5 shows the internal consistency rating based on cronbach alpha values and composite reliability. The results of the analysis showed that cronbach alpha values and the composite reliability values for the five constructs were at 0.693 to 0.948 . This shows good internal consistency (Hair et al., 2014).

Table 6

Standardized Loading, Composite Reliability (CR) and Average Variance Extracted (AVE)

\begin{tabular}{llllll}
\hline Constructs & Indicator & Loading & CR & AVE & $\begin{array}{l}\text { Convergent } \\
\text { Validity }\end{array}$ \\
\hline Knowledge (K) & B1 & 0.735 & 0.924 & 0.668 & YES \\
& B2 & 0.853 & & & \\
& B3 & 0.860 & & & \\
& B4 & 0.847 & & & \\
& B5 & 0.759 & & & \\
& B6 & 0.841 & & & \\
\hline Interpersonal Skills & C7 & 0.882 & 0.932 & 0.733 & \\
(IS) & C8 & 0.824 & & & \\
& C9 & 0.811 & & & \\
& C10 & 0.882 & & & \\
\hline Technical Skills (TS) & C11 & 0.880 & & & \\
& D12 & 0.723 & 0.927 & 0.559 & \\
& D13 & 0.793 & & & \\
& D14 & 0.710 & & & \\
& D15 & 0.761 & & & \\
& D16 & 0.748 & & & \\
& D17 & 0.772 & & & \\
& D18 & 0.817 & & & \\
& D19 & 0.778 & & & \\
& D20 & 0.593 & & & \\
& D21 & 0.760 & & & \\
Teachers' attitude & E23 & 0.807 & 0.828 & 0.619 & \\
towards supervision & E24 & 0.866 & & & \\
\hline & E27 & 0.676 & & & \\
\hline
\end{tabular}

Based on the results of the composite reliability coefficient of evaluation in Table 6 , the value of composite reliability for each construct in the study model namely the supervision of teaching and learning supervision (0.953), knowledge (0.924), interpersonal skills (0.932), technical skills (0.927) and teachers' attitude towards supervision (0.828) was over 0.7 ; thus it shows the model of this study has achieved the required internal consistency (Hair et al., 2017). 


\section{Discriminant Validity}

Table 7

Cross Loading table

\begin{tabular}{|c|c|c|c|c|c|c|}
\hline \multirow[b]{2}{*}{ Constructs } & \multirow[b]{2}{*}{ Dimension } & \multirow[b]{2}{*}{ Indicator } & \multirow{2}{*}{$\begin{array}{l}\text { Second } \\
\text { Order } \\
\text { AtS } \\
\end{array}$} & \multirow{2}{*}{\multicolumn{3}{|c|}{ First Order }} \\
\hline & & & & & & \\
\hline \multirow[t]{21}{*}{ Teaching and Learning Supervision } & Knowledge & B1 & 0.274 & 0.755 & 0.488 & 0.376 \\
\hline & & B2 & 0.463 & 0.857 & 0.659 & 0.568 \\
\hline & & B3 & 0.434 & 0.862 & 0.629 & 0.552 \\
\hline & & B4 & 0.475 & 0.844 & 0.647 & 0.533 \\
\hline & & B5 & 0.442 & 0.747 & 0.570 & 0.468 \\
\hline & & B6 & 0.465 & 0.835 & 0.617 & 0.511 \\
\hline & Interpersonal Skills & $\mathrm{C} 7$ & 0.428 & 0.629 & 0.811 & 0.465 \\
\hline & & $\mathrm{C} 8$ & 0.483 & 0.669 & 0.881 & 0.578 \\
\hline & & C9 & 0.475 & 0.646 & 0.882 & 0.600 \\
\hline & & $\mathrm{C} 10$ & 0.441 & 0.641 & 0.886 & 0.621 \\
\hline & & $\mathrm{C} 11$ & 0.500 & 0.582 & 0.819 & 0.637 \\
\hline & Technical Skills & D12 & 0.467 & 0.446 & 0.539 & 0.710 \\
\hline & & D13 & 0.483 & 0.517 & 0.549 & 0.794 \\
\hline & & D14 & 0.401 & 0.478 & 0.482 & 0.722 \\
\hline & & D15 & 0.397 & 0.470 & 0.519 & 0.773 \\
\hline & & D16 & 0.404 & 0.368 & 0.435 & 0.750 \\
\hline & & D17 & 0.433 & 0.469 & 0.548 & 0.782 \\
\hline & & D18 & 0.494 & 0.520 & 0.533 & 0.820 \\
\hline & & D19 & 0.440 & 0.548 & 0.554 & 0.786 \\
\hline & & D20 & 0.393 & 0.223 & 0.300 & 0.565 \\
\hline & & D21 & 0.529 & 0.505 & 0.568 & 0.749 \\
\hline \multirow[t]{3}{*}{$\begin{array}{lll}\begin{array}{l}\text { Teachers' } \\
\text { supervision }\end{array} & \text { attitude } & \text { towards } \\
& & \\
& \end{array}$} & & E23 & 0.816 & 0.473 & 0.395 & 0.492 \\
\hline & & E24 & 0.862 & 0.466 & 0.548 & 0.530 \\
\hline & & E27 & 0.668 & 0.261 & 0.312 & 0.357 \\
\hline
\end{tabular}

Note: Teaching and Learning Supervision (TLS), Teachers' Attitude towards Supervision (AtS), Knowledge (K), Interpersonal Skills (IS), Technical Skills (TS).

Table 7 indicates each indicator is to achieve discrimination validity when the value of each indicator has the highest value compared to other construct values (highlighted value). 
Table 8

Fornell-Larcker First Order Criteria

\begin{tabular}{lllll}
\hline First Order Constructs & $\mathrm{K}$ & $\mathrm{TS}$ & $\mathrm{AtS}$ & $\mathrm{IS}$ \\
\hline Knowledge (K) & 0.818 & & & \\
Technical Skills (TS) & 0.618 & 0.748 & & \\
Teachers' Attitude towards Supervision (AtS) & 0.525 & 0.594 & 0.787 & 0.544 \\
Interpersonal Skills (IS) & 0.739 & 0.680 & 0.856 \\
\hline
\end{tabular}

AVE > r² (Hair et al., 2010; 2014)

Table 8 shows the value of the AVE square root in the first order construct is greater than the value of all the constructs below it. The AVE square root value refers to the highlighted value while the unhighlighted values refer to the correlation value in the construct. The cause of AVE's squares is greater than the value of the correlation between the constructs. This shows the discriminant validity of the first order construct using the Fornell-Larcker criteria has been achieved in this study (Hair et al., 2017).

Table 9

Heterotrait-Monotrait (HTMT) First Order Criteria

\begin{tabular}{lllll}
\hline First Order Constructs & K & TS & AtS & IS \\
\hline Knowledge (K) & & & & \\
Technical Skills (TS) & 0.668 & & & \\
Teachers' Attitude towards Supervision (AtS) & 0.638 & 0.738 & & \\
Interpersonal Skills (IS) & 0.815 & 0.738 & 0.669 & \\
\hline
\end{tabular}

HTMT 1. 00<1.00 (Hair et al., 2014)

Table 9 shows the results of the Heterotrait-Monotrait Criteria (HTMT). The correlation value between constructs is less than 1.00. This shows that all constructs differ from each other (Hair et al., 2014).

\section{Structural Model Assessment}

The results of the structural model analysis are shown in Figure 3 by fulfilling the criteria of measurement model evaluation based on the Partial least Squares Structural Equation Modeling (PLS-SEM) analysis procedure with the help of Smart-PLS 3.0 software. 


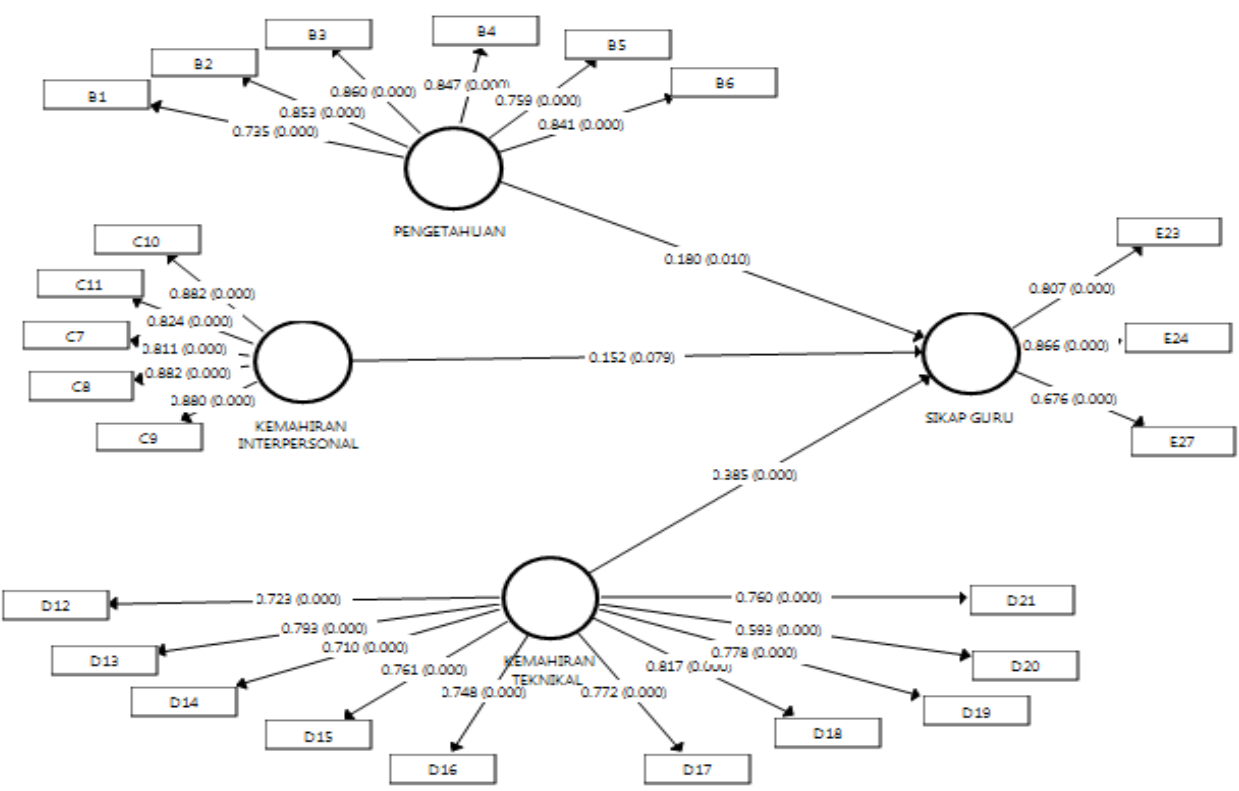

Figure 3

Analysis of the Model Hypotheses

Table 10

Assessment of Significant Relationships in First Order Structural Model

\begin{tabular}{llllll}
\hline Hypotheses & Relationship & Std. Beta & t & p & Findings \\
& & & Value & Value & \\
\hline Hol & $\mathrm{P} \rightarrow$ SG & 0.180 & 2.591 & 0.010 & Significant \\
Ho2 & KI $\rightarrow$ SG & 0.152 & 1.759 & 0.079 & Not significant \\
Ho3 & KT $\rightarrow$ SG & 0.385 & 5.542 & 0.000 & Significant \\
\hline
\end{tabular}

Note: ** Significant at $\mathrm{P}<0.05$ (2-tailed)

Knowledge (K), Interpersonal Skills (IS), Technical Skills (TS), Teachers' attitude towards Supervision (AtS).

Table 10 shows that there was significant influence between the constructs through the path analysis at significance level 0.05 with two-tailed test, $\mathrm{p}<0.05$ and $\mathrm{T}>1.96$ (Imam $\&$ Hengky, 2015). The results of the coefficient of assessment showed that there was significant influence between knowledge dimension $(\mathrm{K})$ and teacher attitude (AtS) $(\beta=$ $0.180, \mathrm{t}=2.591, \mathrm{p}<0.05)$ and technical skill (TS), $\mathrm{t}=5.542, \mathrm{p}<0.05)$. Meanwhile, there is no significant influence for interpersonal skills dimension (IS) with teacher attitude (AtS) $(\beta=0.152, t=1.759, p>0.05)$. The findings explain that changes in variables are influenced by the three dimensions of supervision that become the predictor of improving the attitude of teachers towards the supervision implemented in secondary schools in Kubang Pasu District, Kedah. 


\section{DISCUSSION}

The importance of teaching and learning supervision also directly affects teachers' attitude towards supervision in secondary schools in Kubang Pasu District, Kedah. The findings show that the dimensions of knowledge and technical skills contribute significantly and positively to the attitudes of teachers in secondary schools in Kubang Pasu District, Kedah, while the dimensions of interpersonal skills do not impose significant influence on teachers' attitude towards supervision. Aspects of knowledge, interpersonal skills and technical skills as suggested by Glickman et al. (2004, p. 96) that the three aspects are effective in conducting teaching supervision in schools. Obviously, systematic and planned supervision can help supervisory objectives achieve goals in school.

The dimension of knowledge has shown a significant influence on the attitude of teachers in secondary schools in Kubang Pasu District, Kedah. This is because the teachers in secondary schools in the Kubang Pasu District of Kedah are more confident of the supervision that is capable of guiding the teacher's teaching.Bity Salwana, Ahmad Basri and Mohammed Sani (2010), stated that through supervisory guidance, teachers can adapt their knowledge through opinions, suggestions and information that can improve teachers' teaching in the classroom. Hence, knowledgeable supervisors are able to influence teachers' attitudes towards supervision so teachers can improve teaching in the classroom.

The findings also found that the dimensions of interpersonal skills did not significantly influence the attitude of teachers towards the supervision of schools in Kubang Pasu District, Kedah due to the teacher's resentment attitude towards the atmosphere. The resentment attitude resorts to individualism as a result of the supervision that is considered to disrupt the teaching of the teacher (Mofareh, 2011). As such, teachers assume that they do not need the support of supervisors through interpersonal skills because such support is a threat to their teaching status. Hence, the information can provide input to school management in the Kubang Pasu District, Kedah to establish a culture and supervisory environment to support and improve supervisory execution to be more effective.

In addition, the findings show that the dimensions of technical skills have a significant influence with the attitude towards supervision. The direct impact of technical skills with the attitude of teachers towards supervision in secondary schools in the Kubang Pasu District, Kedah may be due to the skilled supervisor, disciplined and master the latest teaching and learning techniques for having a clear and always on-going goal. The problem of time constraint is not an excuse because as a teaching leader, the supervisor needs to be wise in making decisions and determining priorities. This finding clearly shows that the supervisor has a good relationship with all the teachers. This good relationship can erode feelings of fear, isolation culture and foster good cooperative culture between supervisors and supervised teachers. This shows that the supervisors in the Kubang Pasu District, Kedah are committed and efficient in realizing the supervisory goals effectively as intended by the MOE. According to Dali, Daud and Fauzee (2017), 
the implementation of supervisory policies that existed in schools since 1987 has shown that the school is committed to ensuring that supervisory execution is implemented optimally and can shape the teachers' attitude towards supervision.

However, there are research findings showing that technical skills do not affect teachers' attitudes.Study done by Norlela and Mohd Munaim (2013) found that supervision at school had caused conflicts because the supervisor did not act as a mentor of the teaching profession but was more punitive towards teaching. This is because supervisors are less skilful in managing supervision. Therefore, in order to overcome this deficiency, Sharifah Zainon Syed Lani (2002) thinks that the school should provide supervisory management programs to the parties involved in acquiring skills in conducting supervision at the school.

Through the findings of this study, aspects of information, social skills and technical skills are essential aspects that require to be thought-about within the Kubang Pasu District of Kedah, as these aspects will have an effect on teachers' attitudes towards oversight.Furthermore, the attitude of the teacher is a factor that determines the effectiveness of the classroom supervision which demonstrates the co-operation culture of supervisors with supervised teachers through the supervision of instructional exercises.

Overall, the scale of data, social skills and technical skills are ready to demonstrate expertness between supervisors and supervised teachers. This professionalism coincides with Glickman et al. (2010) emphasizing that knowledge, interpersonal skills and technical skills need to be strengthened in order to enhance teacher professionalism and to establish a positive relationship between supervisor and supervised teacher.

\section{CONCLUSION}

Overall, teachers in SMK in Kubang Pasu district, Kedah who were involved in this study perceived all constructs of independent variables in this study, namely the technical knowledge and skills proved to be effective in ensuring the implementation of classroom teacher supervision. However, the dimensions of interpersonal skills cannot be ignored as interpersonal elements can trigger positive attitude of teachers to improve teaching in the classroom. The findings of this study clearly support Glickman et al. (2004) that knowledge, interpersonal skills and technical skills are needed to achieve the objective of effective classroom teaching and learning supervision in schools. The findings also support the findings of Dali, Daud and Fauzee (2017) that knowledge and technical skills variables have significant influence with the effectiveness of the implementation of integrated teacher teaching in schools. This shows the classroom teaching and learning supervision recommended by Glickman et al. (2004) is a supervision aimed at improving the effectiveness of teacher teaching in the classroom by applying positive attitudes to teachers at school. 


\section{REFERENCES}

Ahmad Kamal Ariffin, A., Rahman, I., \& Zuraidah, A. (2015). Factors Affecting the Teachers' Motivation towards the Implementation of Teaching Supervision in Secondary Schools, Journal of Advanced Review on Scientific Research, 12(1), 1-10.

Bitty Salwana, A., Ahmad Basri, M. Y., Ramlee, M., \& Mohammed Sani, I. (2010). Analisis kompetensi pengetua berdasarkan kualiti peribadi, pengetahuan, kemahiran dan amalan pengurusan sekolah menengah Malaysia. Jurnal Pendidikan Malaysia, 35(2), 31-41.

Ebmeier, H. (2003). How Supervision Influences Teacher Efficacy and Commitment: An Investigation of a Path Model, Journal of Curriculum and Supervision, 18(2), 110141.

Glickman, C. D. (1981). Developmental supervision: alternative practices for helping teachers improve instructions. Association for supervision and curriculum. Boston: Allyn \& Bacon.

Glickman, C. D., Gordon, S. P., \& Ross-Gordon, J. (2004).Supervision and Instructional Leadership: a Development Approach ( $6^{\mathrm{th}}$ ed.). Pearson, Boston.

Glickman, C. D., Gordon, S. P., \& Ross-Gordon, J. M. (2010). Supervision and Instructional leadership: A Developmental Approach (8th ed.). Boston. Pearson.

Hair, J. F., Hult, G. T. M., Ringle, C. M., \& Sarstedt, M. (2014). A Primer on Partial Least Squares Structural Equation Modelling (PLS-SEM). Thousand Oaks: Sage.

Hair, J. F., Hult, G. T. M., Ringle, C. M., \& Sarstedt, M. (2017). A Primer on Partial Least Squares Structural Equation Modelling (PLS-SEM) (2nd ed.). Sage Publications, Thousand Oaks.

Hamdan, S., \& Mohd, A. S. (2011).Penyeliaan pengajaran di sekolah-sekolah kebangsaan daerah Johor Bahru (Thesis master yang tidak diterbitkan). Fakulty of Education, University Teknologi Malaysia.

James Ang Jit \& Balasandran Ramiah. (2012). Kepimpinan pengajaran, satu panduan praktikal. Kuala Lumpur: PTS Publications and Distributor.

Kementerian Pendidikan Malaysia (1987), Surat Pekeliling Ikhtisas bilangan 3/1987: Penyeliaan Pengajaran dan Pembelajaran Di Dalam Kelas oleh Pengetua/Guru Besar sekolah, KP (BS) 8591/Jld II (77), Kementerian Pelajaran Malaysia, Kuala Lumpur.

Kementerian Pendidikan Malaysia (2013), "Pendidikan prasekolah hingga lepas menengah", Pelan pembangunan pendidikan Malaysia 2013-2025, Malaysia (pp. 4-24).

Mardhiah, J., \& Rabiatul Adawiyah, A.R. (2016, July).Hubungan kualiti penyeliaan pengajaran dengan efikasi kendiri guru. Working paper, Universiti Sains Malaysia. 
Mat Rahimi, Y., \& Mohd Yusri, (2015). Sumbangan instruksional maya terhadap kompetensi pengajaran guru. E-Proceeding of the Intenational Conference on Social Scince Research.

Mat Rahimi, Y., \& Mohd Yusri, I. (2014). Model Konsep Kepimpinan Instruksional Maya, Pola Komunikasi dan Kompetensi Pengajaran guru. Seminar Pengurusan dan Kepimpinan Pendidikan ke-21. Genting Highlands.

Meor Ibrahim Kamaruddin \& Norziana Anuar. (2008). Tinjauan terhadap tahap penyeliaan guru pembimbing terhadap guru pelatih semasa menjalani latihan mengajar. Jurnal Pendidikan. Fakulti Pendidikan. Skudai : Universiti Teknologi Malaysia.

Mofareh, A. (2011).School-based instructional supervision in Saudi Arabian Public Secondary School (Unpublished doctoral dissertation thesis). Department of Education, Universiti of York.

Mohd Munaim, M. (2013). Pengaruh Kepimpinan Instruksional Guru Besar Ke Atas Efikasi Guru. Jurnal Kurikulum dan Pengajaran Asia Pasifik, 2(1), 11-25.

Mohammed Sani. (2013). Peranan guru kanan mata pelajaran dalam mempertingkatkan kualiti pengajaran guru-guru. Jurnal Kurikulum dan Pengajaran Asia Pasifik 1(1), 2841

Mohd Yusri, I., \& Aziz, A. (2015). Model Kepimpinan Maya dan Kesejahteraan Kerja Pemimpin Sekolah Malaysia: Perantaraan oleh komunikasi Dalam Kumpulan. Jurnal Kepimpinan Pendidikan, 2(1), 1-10.

Pelan Pembangunan Pendidikan Malaysia 2013-2025. Pendidikan prasekolah hingga lepas menengah. Kementerian Pendidikan Malaysia, (2013). (pp. 4-24)

Puteri Darishah Dali, Yaakob Daud \& Mohd Sofian Omar Fauzee. (2017). Teaching and Learning Supervision by School Management, Attitude of Teachers and Competency of Teaching, International Journal of Development and Sustainability, 6(10), 1367-1381.

Rafisah, O. (2009). Hubungan kualiti penyeliaan pengajaran dan pembelajaran dengan komitmen dan efikasi guru. Tesis kedoktoran yang tidak diterbitkan. Universiti Utara Malaysia.

Rekkeman, K. (2015). Amalan dan pendekatan pencerapan klinikal dalam praktikum serta impaknya terhadap kualiti guru pelatih. Jurnal Tinta Artikulasi Mmenbina Ummah, 1(1), 41-51.

Sharifah Zainon Syed Lani. (2002). Keberkesanan amalan penyeliaan pengajaran oleh pentadbiran sekolah di salah sebuah sekolah menengah di daerah Kota Tinggi, Johor. Disertasi Sarjana yang tidak diterbitkan. Institut Pengajian Kepengetuaan, Universiti Malaya.

Shamsudin, M., \& Kamarul, A. J. (2011).Penyeliaan guru dalam pengajaran dan pembelajaran. UTM Press, Johor Bharu, Malaysia. 
Shukri Zain. (2011). Penyeliaan pendidikan: Teori dan amalan. Emeritus Publications, Tanjong Malim.

Wan Shafira Wan Zaki. (2011). Aplikasi gaya penyeliaan pengajaran guru pembimbing dalam pengurusan latihan mengajar. Tesis Sarjana yang tidak diterbitkan. Fakulti Pendidikan. Skudai: Universiti Teknologi Malaysia.

Vijayaamalar, G., \& Suhaida, A. K. (2013). Sikap guru terhadap penyeliaan pengajaran yang dijalankan di sekolah menengah kebangsaan, zon Bangsar, Kuala Lumpur. Paper presented at the School of Education, University Putra Malaysia (GREDUC). 